\title{
DUAL ALLEGIANCE IN THE GERMAN LAW OF NATIONALITY AND AMERICAN CITIZENSHIP
}

\author{
THEO. H. THIESING \\ of the District of Columbia Bar
}

Recently, a United States district court in refusing naturalization to a German petitioner ${ }^{1}$ under Section 2I7I of the Revised Statutes, ${ }^{2}$ as ${ }^{\circ}$ construed by that court, ${ }^{3}$ said that "any doubt as to the meaning of our law should be construed against their [meaning German petitioners'] admission." In reaching its conclusion the court was influenced by its interpretation of the German law of nationality of July 22, rgI3, and particularly of Section 25, which the court undertook to notice judicially, the court concluding that this section permits German nationals to retain their German nationality on becoming naturalized in a foreign country; adding, "Some of the provisions [of the German law] are wholly contrary to, and at variance with, our ideas of the obligations of a naturalized citizen. No divided allegiance is tolerated by our law." Whether or not the court was correct under our rules of evidence in taking judicial cognizance of such foreign law need not be discussed

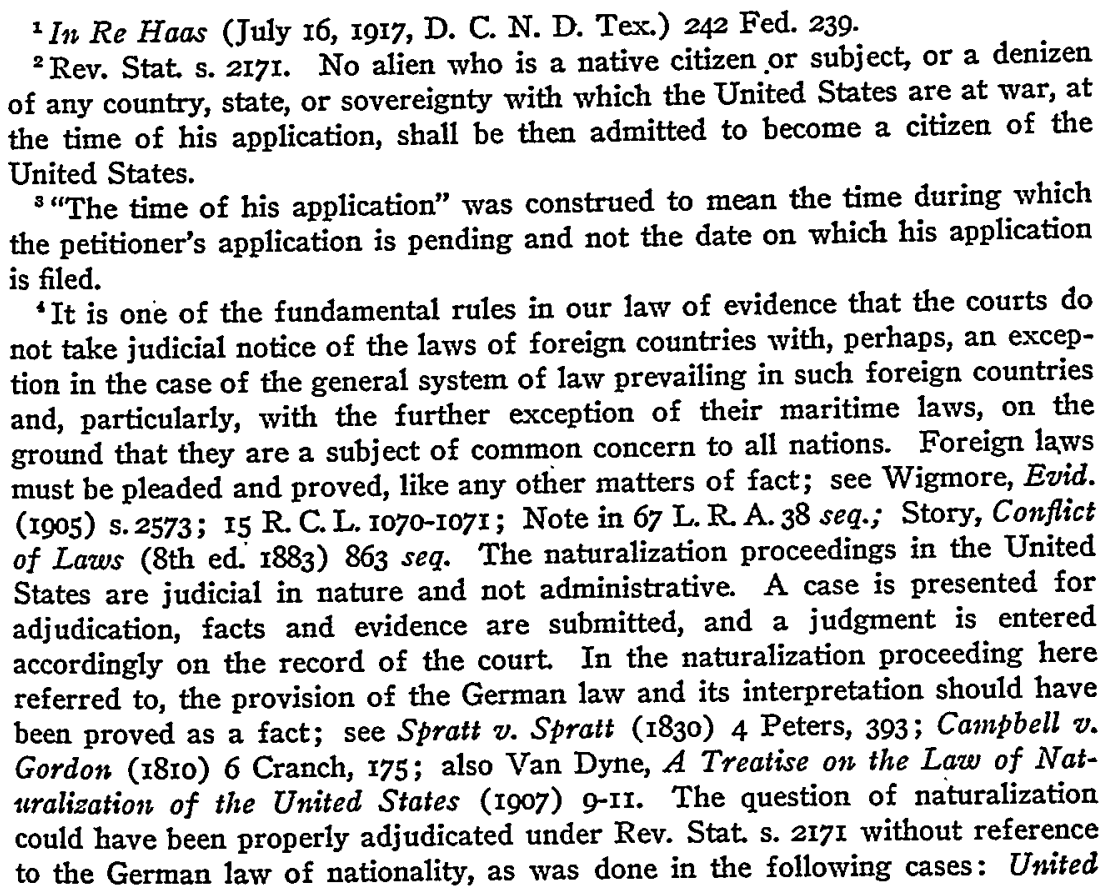


here, but the court's interpretation of Section 25 of the German nationality law, in view of the public interest which has attached to that statute, warrants careful examination.

The court's interpretation of the particular section of the German nationality law seems to have been largely influenced by statements in the press and articles ${ }^{5}$ written by public men in magazines of wide

States v. Meyer (April I2, r9I7, C. C. 2 C.) 24I Fed. 305; In Re Jonasson (April 28, 1917, D. C. Md.) 24I Fed. 723; In Re Kreuter (May 25, 1917, D. C. S. D. Cal.) 24I Fed. 985; In Re Naturalization of Subjects of Germany (May I4, I9I7, D. C. E. D. Wis.) 242 Fed. 97I ; Ex Parte Borchardt (June 28, I917, D. C. E. D. S. C.) 242 Fed. 1006; In Re Nannanga (July 5, I9I7, D. C. S. D. Ga.) 242 Fed. 737; $c f$. note on these cases in (Nov. I9I7) 27 YALE LAW Journal, I28. Assuming the court's interpretation of the German law in In Re Haas, supra, to be correct, would the decision not be in conflict with the laws and practice of the United States, which refuses to recognize any limitation upon expatriation? Naturalization papers are granted to aliens here notwithstanding any legal restrictions in the law of their native country which do not recognize foreign naturalization. See Supplemental Note, p. 507 post.

${ }^{-}$Of the numerous references to and adverse comments on the question of dual allegiance in the German law only a few need be mentioned here. Gibbons, The New Map of Europe (1914) 34-35:

"A legal means has been given to these naturalized Germans to retain, without the knowledge of the nations where their oath of allegiance has been received in good faith, citizenship in Germany."

The same author: The Menace of 'Paragraph Twenty-Five' 205 NoRTH Ax. REv. 560-565, replying to J. Mattern's article, Paragraph 25 in the New German Citizenship Law, 204 NoRTH AM. Rev. 856-868. See also Theodore Roosevelt in his article When is an American not an American? (June I9r5-No. 2) 42 METROpolitan MaG. I5, in which he calls the State Department to account for the position taken in the case of P. A. Lelong, Jr., of New Orleans, involving the question of dual allegiance under his American citizenship and his liability in France for performance of military service. He also takes occasion to refer to the German law of nationality and places the following interpretation upon it:

"Two or three years ago it was announced that Germany had passed a law by which she provided for her citizens, who became naturalized in the United States or elsewhere the means of also retaining their German citizenship, so that these men would preserve a dual citizenship."

R. W. Flournoy in his article on Problems of Dual Nationality in Time of War, N. Y. TIMEs, Sept. I2, I9I5, v. I7, replies, although not speaking in his official capacity as chief of the Bureau of Citizenship in the State Department, yet with expert knowledge, to Mr. Roosevelt's criticism of the Department's stand in the particular case and to his comment on the German law, leading Mr. Roosevelt ad absurdum. Rear Admiral Casper F. Goodrich, U. S. N. (ret.) goes a step further in his article Why Stranger in Our Gates remains an Alien, N. Y. TIMes, June 24, I9I7, v. I4. He says that "this law undermines the validity of any naturalization paper issued to a person of German birth," and proposes "to cancel all German naturalization papers and to issue no more until the Delbrück law (the German law of nationality of I9I3) is repealed."

France passed a law on April 7, I9I5 (Duvergier, Lois, Décrets, etc., 1915, II6) and issued a decree on April 24, I9I5. (2 Sirey, Législation de la Guerre de IgI4I915, I35) in execution thereof, ordering the denaturalization by an administrative proceeding of naturalized French citizens of enemy origin who have pre- 
circulation which have created and propagated a misunderstanding of a certain provision of this German statute relating to dual nationality, giving rise to the assumption that a German subject, naturalized in the United States, could by the German law of July 22, I9I3, retain his

served their former national character, and under the administrative regulations, 94 certificates out of 758 granted since Jan. I, I913 to former subjects of the Central Powers have been revoked. This law has been superseded by the law of June I8, x9I7 (Journal officiel, 20 Juin 19I7) providing for cancellation by the courts of naturalization certificates granted since January I, I9r3 to persons of enemy origin who have preserved their former nationality. All persons are to be deprived of their naturalization papers when it appears from their conduct that they have conserved "attachment" to their country of origin. The government will not wait until a disloyal act has been committed, but will take measures compatible with the interests of the country and will denaturalize and intern these persons on the presumption that they have retained their original national character. See Journal officiel Chambre des Députés. Doc. Sess. ord. Igr6, V. 2. No. 229I, pp. I055-1058; Sénat. Doc. Sess. ord. ror6. Annexe No. 447 , pp. 598-6or, containing also a discussion of the German law.

GREAT BritatN is considering an amendment to the Nationality and Status of Aliens Act, I9I4 so as to provide for revocation of naturalization certificates for reasons other than false representations or fraud. In the memorandum submitted to the Imperial War Conference, r9I7, references are made to the German law of nationality which in paragraph 25 allows, according to the interpretation by the Home Office, naturalized British subjects of German origin to retain their original nationality. See Imperial War Conference, London, I9I7, Extracts from Minutes of Proceedings. 7 Geo. V, A, I9I7. Sess. Pap. No. $42 \mathrm{a}$, pp. 70-78, 160-166, being a reprint of Paper by Command 8566 . See also Schuster, Nationality and Naturalization, Jan. I917, ConteMroraRY REv. 93-99, recommending amendments to the British act.-Of great interest is a test case tried in the English courts and finally affirmed by the House of Lords-Rex $v$. Halliday, 52 LAw Journal, London, No. 2677, May 5, I917, I73. The appellant, who was born in Germany, became a naturalized British subject in I905. Upon the order of the Home Secretary issued under Regulation $14 \mathrm{~B}$ of the Defence of the Realm Regulations, he was deprived of his liberty and interned together with alien enemies "in view of his hostile origin and associations." Lord Shaw, in a very interesting dissenting opinion, arrays the great charter, the petition of right, liberty of opinion, and other constitutional rights of an English subject against the arbitrary acts of the government.

Portugal by decree No. 2355 of April 23, igi6 (Journal du Droit InterNATIONAL Profe (Clunet, I9I7) 794) ordered the cancellation of all naturalization certificates granted prior to the declaration of war to individuals of enemy origin, and authorized the expulsion of such persons and those of enemy origin but having another or Portuguese nationality whenever their presence in Portugal should be deemed to constitute a menace.

Canada passed in Sept. I9I7 a War-time Elections Act (see text of the Act in Instructions for the Guidance of Returning Officers, Their Deputies and Enumerators, p. 21 seq.) which provides in ch. $6, \mathrm{~s} .67, \mathrm{par} . \mathrm{h}$, for the disfranchisement of all naturalized British subjects who were born in an enemy country and naturalized subsequent to March $3 \mathrm{x}$, I902.

ITALY suspended, by decree of July 25, 1915 (4 Leggi $e$ Decreti, 1915, 3175) the operation of the naturalization provisions of the law of June 13, IgI2 (2 Leggi e Decreti, I9I2, I490). 
German citizenship. Great legal and political importance has been given to this view.

How potent has been the influence of this misunderstanding of the German law is evidenced by the fact that a bill was introduced during the last session of Congress "to prevent the naturalization of aliens who seek or are permitted to retain their citizenship under the state or sovereignty of which they are citizens or subjects." This proposed amendment to the naturalization act would seem to have had in mind German aliens who apply for naturalization papers. ${ }^{7}$

In the following pages the writer hopes that he will be considered as rendering a service in the interests of legal accuracy by endeavoring to demonstrate the erroneous character of the prevailing view, and to arrive at a correct interpretation of the German law in so far, at least, as the United States is concerned.

I

It is within the exclusive domain of the municipal law of every sovereign state to decide when and under what conditions an individual loses or acquires its nationality. By the process reciprocal obligations are imposed, the individual being released from his allegiance and the state from extending its protection, or the individual being invested with the national character and the state extending protection to him. The different states do not, however, follow uniform rules in the determination of a person's nationality, and the law of nations ${ }^{8}$ con-

'Senate Bill No. 1485. 65th Cong., Ist Sess., April 9, rgr7 by Mr. Sterling. No action was taken. The proposed law was intended as an amendment to the Naturalization Act of June 29, I906 (34 Stat. L. 596) and provided:

"Be it enacted, etc., That no alien, although otherwise qualified under the laws of the United States to become a citizen thereof, but who, before seeking admission to such citizenship, has applied for or obtained the consent of the authorities of the foreign state or sovereignty of which such alien is at the time a citizen or subject to retain his citizenship under such foreign state or sovereignty or who has in any form or manner reserved any right under the laws of such foreign state or sovereignty to retain such foreign citizenship while a citizen of the United States, shall be admitted to become a citizen of the United States."

"It was probably overlooked by the persons interested that Russia, Turkey, Italy, France (in. the case of men under 42), and Switzerland, to mention but a few countries, prohibit their subjects from acquiring foreign naturalization without consent of the country of origin, so that whenever we naturalize a subject of those countries who has not obtained special consent thereto from his native country we are naturalizing a person who is still claimed in every respect as a citizen of his country of origin. See Supplemental Note, p. 507 post.

${ }^{8}$ L'Institut de Droit International adopted at its meeting in Venice on Sept. 29 , I896, a resolution relating to conflicts of laws of naturalization and expatriation. Only Arts. 5 and 6 are of interest here. Art. 5. No person may be admitted to naturalization in a foreign country unless he proves that his country of origin has released him from his allegiance, or that he has, at least, made known his intention to his country of origin, and has fulfilled the military 
tains no provision concerning the acquisition and loss of nationality except as to conquest and cession. Cases of conflicts will necessarily arise unless countries with divergent laws have by agreement removed the cause of potential conflicts. Thus, under incongruous principles an individual may possess a dual nationality acquired either (a) by birth-where the state wherein the child is born ( $j u s$ soli) and the state of which the parents are citizens (jus sanguinis) both claim the child as a subject - (b) by marriage, (c) by legitimation of illegitimate children, or (d) by naturalization. Any individual who intentionally or unintentionally possesses such dual nationality, is hardly in an eviable position. Two different states claim his allegiance and demand the duties and obligations owed under it. Awkward as his position is under ordinary circumstances, his status will make him the subject of an irreconcilable conflict of duties in case a serious controversy should engage the two countries. ${ }^{10}$

obligations during the period prescribed for active service in conformity with the laws of such country. Art 6 . No person may lose or renounce his nationality unless he proves that he is complying with the conditions requisite for obtaining his admission in another country. Loss of nationality may never be inflicted as a punishment. (I5 Annuaire de l'Institut de Droit International, 27I.) inf., however, v. Bar, The Theory and Practice of Private International Làw (2d ed. 1892) 195; Weiss, Erwerb und Verlust der Staatsangehörigkeit, Kritik und Reformvorschläge (Annalesn des Deutschen Reichs 1908, pp. 836, 902; 1909, pp. $383,472)$. .

'See arrangement of countries under the jus sanguinis and jus soli by Zeballos, La Nationalité (19I4) 246, 632; slightly different classifications may be found in v. Keller und Trautmann, Kommentar zum Reichs- und Staatsangehörigkeitsgesetz (1914) 38-42; see also Verhandlungen des Reichstags. XIII. Legislaturperiode. I. Session, 1912. Anlagen No. 4, pp: 72, 78.

${ }^{10}$ As to dual nationality and questions of nationality in general see more in detail: v. Bar, The Theory and Practice of Private International Law (2d ed. I892) S. 4I-103; Bluntschli, Das moderne Völkerrecht der civilisirten Staaten als Rechtsbuch dargestellt (1878) 211-227; Bodmann, Die Rechtsverhältnisse der sog. 'Sujets mixtes,' I2 Archiv fiir öffentliches Recht, 200, 317; Bonfils, Manuel de Droit International Public (7e éd. I912 by Fauchille) Nos. 410-432; Borchard, Diplomatic Protection of Citizens Abroad (1915) s. 253-262, and passim; 2 Calvo, Le Droit International (5e éd. I896) s. 539-654; Cockburn, Nationality (1869); Cogordan, La Nationalité (2e éd. 1890); Folleville, Traité Théorique et Pratique de la Naturalization (1890); Fromageot, De la Double Nationalité des Individus et des Sociétés (I892); Hall, $A$ Treatise on International Law (6th ed. I909) ch. V; I Halleck, International Law (4th ed. I908 by Baker) 430-469; Hartmann, Institutionen des practischen Völkerrechts in Friedenszeiten (1874) s. 79-82; Heffter, Das Europäische Völkerrecht der Gegenwart (8th ed. 1888 by Geffcken) 2s. 59, 60; Kahn, Gesetzeskollisionen s. 16 (30 Jhering's Jahrbïcher I-I43); 2 Kent, Commentaries (14th ed. I896) 61-103; 3 Laurent, Droit Civil International (1880) 174-437; Lehr, La Nationalité dans les Principaux Etats au Glabe (1909); Liszt, Das. Völkerrecht (9th ed. I913) I02-104; 2 Martens, Völkerrecht (1886) s. 43-48; Martitz, Das Recht der Staatsangehörigkeit im internationalen Verkehr (Hirth's Amnalen des Deutschen Reichs. Jahrg. 1875, 794-835, III4-II70) ; 3 Moore, History and Digest of International Arbitrations 
Naturalization, as that phase of acquisition and loss of nationality to which we propose to confine our attention, may create the above mentioned dilemma, since the naturalizing state grants naturalization in accordance with its own laws regardless of the fact as to whether or not the naturalized person ceases to be or remains a subject or citizen of his native state.

Paragraph I of Section 25 of the present German law of nationality ${ }^{11}$ provides that

"A German who has neither his domicile nor permanent residence in Germany loses his nationality ${ }^{12}$ upon the acquisition of a foreign nationality where the latter is acquired on his voluntary application or on the application of the husband or legal guardian; in case of a married woman or ward, however, only if the conditions are fulfilled under which expatriation may be applied for according to Sec. I8 and I9." 13

(I898) Ch. LIV; 3 Moore, Digest of International Law (I906) 5 I8 seq.; I Oppenheim, International Law (rgr2) s. 293-313; 3 Pradier-Foderé, Traité de Droit International Public (1887) Nos. I654-1691; I Rivier, Principes Du Droit des Gens (1896) 303-306; I Sieber, Das Staatsbürgerrecht im internationalen Verkehr (1907); Stoerk in 2 Holtzendorffs Handbuch des Volkerrechts (1887) s. II3 seq.; Taylor, $A$ Treatise on International Law (Igor) s. I69 seq.; Ullmann, Völkerrecht (2d ed. I898) s. 97-Ior ; Westlake, International Law (2d ed. I9I0) 228-232; I Weiss, Traité Théorique et Pratique de Droit International Privé (2d ed. 1907)-La Nationalité; Wheaton, Elements of International Law (4th ed. I904 by Atley) 238-25I ; Zeballos, La Nationalité (I9I4).

${ }^{11}$ Reichs-und Staatsangehörigkeitsgesetz. Vom 22. Juli I9I3; Reichs-Gesetzblatt 19I3, 583-593.

12 According to s. I of the law, "Anyone who possesses the nationality of a Federal State or direct Imperial nationality is a German." The term "nationality" for the German word Staatsangehörigkeit seems to be the most appropriate inasmuch as it disregards differences in constitutions and forms of government. It is used here not in its racial, but in its political and legal sense like the term "citizen" in our law, and denotes the political membership in a nation and the bond which attaches an individual to the state. (Cf. v. Bar, op. cit. III-II2.) The German law of nationality does not use the term "citizen" which is generally used to indicate the holder of political rights and privileges in a state. The term is employed, however, in Germany when an individual has acquired political and civic rights in a city.

${ }^{13}$ "S. I8. The expatriation of a married woman may only be applied for by the husband, and, if he is a German, only at the same time as his own release. The application requires the wife's assent.

"S. 19. The expatriation of a person who is subject to parental authority, or who is under the care of a guardian, may be applied for only by the legal guardian, and only with the assent of the German Court for the Protection of Wards (Vormundschaftsgericht). The State Attorney's Office (Staatsanzeltschaft) has the right to appeal against the decision of the Court for the Protection of Wards; further appeal against the decision of the court hearing the appeal is admissible without restriction.

"The assent of the Court for the Protection of Wards is not required if the father or the mother apply for expatriation for themselves and at the same time for a child, on the strength of their parental authority, and if the person making the application has charge of the child. If the person appointed to assist the mother also has charge of the child, the mother's application for the expatriation of the child requires the assent of such person." 
This new provision is not found in the repealed German law of nationality ${ }^{14}$ and expresses unambiguously the legal maxim, not new to other countries ${ }^{15}$ but novel to German legislation, that the acquisition of a foreign nationality affects the loss of the original nationality. ${ }^{10}$ It takes the place of the abolished provision ${ }^{17}$ that uninterrupted

${ }^{14}$ Gesetz über die Erwerbung und den Verlust der Bundes- (Reichs-) und Staatsangehörigkeit. Vom I. Juin I870 (Reichs-Gesetzblatt 1870, 355-373) s..2r, par. 3, however, recognizes the principle of the Bancroft treaty referred to below. ${ }^{25}$ See Supplemental Note at the end of this article.

${ }^{16}$ This maxim should not be confused with the right to emigrate or the right of expatriation. Among the modern states to recognize these rights in their fullest extent Prussia was one of the first: see Kapp, Der deutsch-amerikanische Vertrag vom 22. Februar 1868, 35 Preussische Jahrbiicher (1875) 510 seq.

It may be of interest to note that the United States is largely responsible for the general adoption of a principle first embodied in the French Constitution of Sept. 3, I79r. Acording to Titre II, Art. 6, No. I (see 3 Duvergier, Lois (2e éd.) 242) French nationality is lost by naturalization in a foreign country. Yet, this maxim was never formally incorporated in our statutes until the passage of the Act of March 2, 1907, s. 2 (34 Stat. L. I228), though the Courts (see Talbot v. Janson (1795) 3 Dall. I33;J. Inglis v. Trustees of the Sailors Sing Harbor (I830) 3 Pet. 99; M'llvaine v. Coxe's Lessee (I804) 2 Cranch, 280) and the Executive (see 3 Moore, Dig. of Int. Law s. 431-438) have acted in accordance with such principle. Before that time the rule of the English common law "Once a subject, always a subject" and Nemo patriam exuere potest. was still the law of the land, though not always strictly applied. Kent says in his Commentaries, II, 7I:

"From this historical review of the principal discussions in the federal courts on this interesting subject [expatriation] in American jurisprudence, the better opinion would seem to be, that a citizen cannot renounce his allegiance to the United States without the permission of government, to be declared by law; and that as there is no existing legislative regulation on the case, the rule of the English common law remains unaltered."

(See also Ainslie v. Martin (1813) 9 Mass. 454.) The Act of July 27, I868 (I5 Stat. L. 223), being the result of English-American controversies over the participation of naturalized American citizens in the Fenian movement (see Cockburn, op. cit. 70-ro6) declares "the right of expatriation" to be "a natural and inherent right of all peoples." The act, although apparently a general declaration, is directed against foreign governments and refers merely to people of other countries residing in the United States. This becomes quite evident from reading the debates in Congress (see Congressional Globe 1867-68, 40th Cong. 2 d Sess. $783,831,865,967$, I012, 1098, II27, II56, 1160), where frequently requests were made that the right of expatriation of American citizens should also be expressly stated by an enactment. See also H. Doc. No. 326, 54th Cong. 2d Sess. 24 seq. Only by implication and inference may the declaration of the act, as passed, be applied to citizens of the United States who seek to expatriate themselves (see the opinion of Atty. Gen. Williams, I4 Op. $295 ; 3$ Moore, Dig. of Int. Law, s. 439; also v. Martitz, op. cit. Ir57-I167; Knapp, op. cit. 513-524).

${ }^{17}$ Law of June $\mathrm{r}$, 1870, supra, s. 13, 2I. If a German acquired a foreign nationality during this period of prescription, he was regarded by the German government for all intents and purposes as a foreigner, and if he had not acquired any foreign nationality before the expiration of ten years he became heimatlos - a man without a country. It is the tendency of the new nationality law to facilitate repatriation of former Germans, but the law does not auto- 
residence abroad for to years entails, as a matter of course, loss of German nationality, by prescription, and embodies the principle formally acknowledged by the concessions made in the Bancroft Treaties of $1868,{ }^{18}$ that the citizens or subjects of one of the contracting parties who become naturalized within the jurisdiction of the other, and who shall have resided therein uninterruptedly for five years, are to be treated as naturalized citizens or subjects of the latter. We shall have occasion, presently, to indicate the relation of the recent German law of 1913 to such treaties.

The loss of German nationality no longer occurs merely because of a failure to comply with a formality. ${ }^{19}$ On the contrary, circumstances must now exist which clearly indicate the intention of the particular person to cease to be a German subject. ${ }^{20}$ Such intention is expressed by the voluntary application for foreign naturalization. The application is an expression of will, a voluntary act, and constitutes, even if not expressed in definite words, a renunciation of the former allegiance, and at least, upon principle, an act incompatible with the retention of another nationality. The German law requires that the acquisition of a foreign nationality must rest upon a positive expression of the will, which is found when a person files a petition for naturalization according to the laws of a foreign state and becomes thereupon a national of the latter.

A mere application for naturalization or the declaration of intention to become a citizen at a future time will not, however, suffice. The complete acquisition of foreign nationality effects an automatic loss of the German nationality, if no domicile or permanent residence

matically repatriate all heimatlos persons. Such individuals desiring to reacquire German nationality may be naturalized like any other foreigner, in accordance with s. 8-12, 14-16, or they may, according to s. $x_{3}$, be repatriated in certain cases, referred to in the text below, upon their petition the grant of which lies entirely within the discretion of the German authorities. The law does not vitiate the grounds upon which German nationality has been lost before Jan. I, rgr4, the date it went into effect. It seems, therefore, that all persons domiciled in this country who had lost their German nationality for any reason prior to Jan. I, I9I4, have taken no steps for repatriation and have not become naturalized American citizens, are heimatlos-i. e., legally they are not Germans, and logically are not subject to disabilities and restrictions as such.

${ }^{13}$ See post, p. 495 et seq.

${ }^{10}$ The requirement was registered in a German consul's office, Law of June I, I870, S. 2I.

${ }^{20}$ According to s. $17-29,32$ of the new German nationality law, nationality is also lost by expatriation, and noncompliance with military obligations [our American law provides that in case of desertion or avoiding the draft in time of war rights of citizenship are forfeited; such forfeiture may be remitted. Rev. Stat. s. I996-98 as amended by Act of Aug. 22, 1912, ch. 336, s. I, 37 Stat. L. 356], legitimation of illegitimate children by a foreigner, marriage (in the case of a German woman marrying a foreigner), or by the declaration of the German authorities (in the case of a German residing abroad who, although able to do so, fails to join the colors in case of war or mobilization). 
is maintained in Germany, without requiring any other act on the part of the German authorities; the limitations upon the release from German allegiance provided in Section 22 of the law ${ }^{21}$ do not apply, and the German government treats the individual naturalized in another country as a foreigner to all intents and purposes. All legal relations which are inconsistent with his new status cease to exist, notwithstanding his German origin or language. ${ }^{22}$ If, however, the naturalized person's conduct-as, e. g., noncompliance with military obligations ${ }^{23}$-before the acquisition of the foreign nationality rendered him liable to criminal or disciplinary prosecution, his new nationality will not protect him against .eventual punishment when coming within the jurisdiction of the German law, unless the Bancroft treaties concluded with the United States prevent it. ${ }^{24}$

${ }^{2}$ Under s. 22 of the law expatriation or release from German nationality is not granted to the following classes of persons:

"I. To persons liable to military service, as to whose liability to serve no definite decision has yet been given, unless they produce a certificate from the definite decision has yet (Ersatzkommission) to the effect that in the opinion of the commission expatriation is not applied for with the intention of avoiding liability to active service;

"2. To men of the active army, the active navy, or the active colonial troops;

"3. To men of the reserve of the class defined in s. 56, Nos. 2-4, of the Imperial Military Law, unless they have received the consent of the Military authorities;

"4. To other men of the reserve after they have been called to active service;

"5. To officials and officers, including those of the reserve, before they have been discharged from service;

"Expatriation may not be refused in times of peace for reasons other than those mentioned in paragraph $I$. In time of war and danger of war the right is reserved to the Emperor to issue special decrees."

${ }^{22}$ Entwürfe nebst Begrïndung. Verhandlungen des Reichstags. XIII. Legislaturperiode. I. Session, IgI2. Anlagen. Drucksache Nr. 6, p. I5-16; also v. Keller und Trautmann, $o p$. cit. 287-29o.

${ }^{23}$ Sec. 140 of the German Penal Code punishes for noncompliance with military obligations the following classes of persons:

"I. Persons liable to military service who without permission and with the intent to escape service in the standing army or the navy, either leave the Empire, or after reaching military age remain outside of the Empire-by a fine of not less than I50 marks nor more than 3,000 marks, or by imprisonment for not less than one month nor more than one year.

" 2 . Officers or medical men ranking as officers of the reserve who emigrate without permission-by a fine not exceeding 3,000 marks, or by arrest or imprisonment not exceeding six months.

"3. Any person liable to military service who, after proclamation by the Emperor of a special regulation during a period of ,war or danger of war, emigrates contrary to such proclamation-by imprisonment not exceeding two years to which may be added a fine not exceeding 3,000 marks. Any attempt is punishable.

"The property of the accused may be attached in so far as is necessary in the opinion of the judge to cover the highest fine which may possibly be imposed upon the convicted person, and the costs of the proceedings."

(Henle und Schierlinger, Das Strafgesetzbuch fiir das Deutsche Reich (I9I2) I42.)

${ }^{24}$ See v. Keller und Trautmann, $o p$. cit. $29 \mathrm{I}$; as to cases of punishment for breach of military obligations see 3 Moore, op. cit. 363 seq., 564 seq.; Tingle, Germany's Claims upon German-Americans in Germany (Ig03). 
A certain perplexity is caused by paragraph 2 of Section 25 which provides as follows:

"[German] nationality is not lost by one who before acquiring foreign nationality has applied for and obtained the written consent of the competent authorities of his home State to retain such nationality. Before this consent is given, the German Consul is to be heard."

The principle proclaimed in the first paragraph of Section 25 that

"a German who has neither his domicile nor permanent residence in Germany loses his nationality upon the acquisition of a foreign nationality where the latter is acquired on his voluntary application"

has thus apparently been limited. In express terms, the legal anomaly of dual nationality seems to be recognized. The language employed in the second paragraph of Section 25 gives apparent ground for the erroneous interpretation of some writers, as will be shown hereafter, because such language is rather sweeping and conveys the impression that the possession of a dual nationality is generally allowed, and that a German residing abroad may acquire a foreign nationality without losing his German nationality. Such a general application of the provision was, however, not sanctioned or intended, as a closer examination of the subject fully reveals.

While it is a familiar legal doctrine that the language of a law determines its sense, it is, nevertheless, common practice to go beyond the surface meaning of words used, especially where they would indicate a departure from universally recognized principles, and to consider the origin and history of the statute, the motives which prompted its adoption, and the attending circumstances,-particularly legislative committee reports and debates-to determine, in case of doubt, the true meaning and application of a law. The German courts in particular resort to the preparatory legislative material in order to determine the purpose of a law and to interpret the intention of the legislator. ${ }^{25}$

An examination of the explanatory remarks which accompanied the bill when introduced by the government in the Reichstag, of the committee report on the bill, and of the commentaries on the law, discloses the attitude which the German government has taken with reference to the question of dual nationality and clearly indicates the scope of the law itself.

When introducing the Bundesrat's bill in the Reichstag, Dr. Delbrück, then Minister of the Interior, presented the point of view of the government with regard to dual nationality by saying that persons owing allegiance to more than one country were of no benefit to such countries, they rather constituted a burden, and spoke of double

\footnotetext{
${ }^{25}$ As to such practice in the German courts see Düringer, Richter und Rechtsprechung (Ig09) 13-25; Rumpf, Gesetz und Richter (1906) I20 seq.
} 
allegiance as an anomaly, ${ }^{28}$ indicating thereby the government's antipathy to the existence of such a status.

This attitude was even more clearly emphasized during the discussion at the first reading of the Bundesrat's bill in the Reichstag committee. The question of dual nationality was there raised by one of the members, who declared that as a matter of principle dual nationality should be avoided, and that the possibility of a dual nationality would be inconsistent with the idea of allegiance owed by a German; for a person could owe only single allegiance. He, therefore, moved to strike out paragraph 2 of Section 25. The representative of the Bundesrat in defending paragraph 2 explained the attitude of the several states of the empire towards the question of dual nationality, and stated the reasons for the proposed provisions and their scope. $\mathrm{He}$ said that several of the federal states had taken the position that a plural international citizenship was extremely undesirable; that it could not, however, be completely abolished in fact, and must be allowed for practical purposes and in emergencies. Such dual nationality, as proposed by the provisions of paragraph 2, would exist where a German might acquire a foreign nationality automatically, as he would in any foreign country where the $j u s$ soli governed the matter. In that instance, it would certainly be very unjust to declare that a German had forfeited his nationality. Circumstances might also exist which would force a German to acquire foreign nationality without giving up his German nationality in order to protect his economic interests. ${ }^{27} \mathrm{He}$ referred to the laws of several countries, particularly to the law of Russia which prohibits foreigners from acquiring and owning real property. Should, for instance, a German inherit real estate situated in such a country, the material welfare and interests of his family might demand the retention of such property. Since his precarious legal position would be known to possible purchasers of such property, they would naturally hold back their offers until the expiration of the time limit would force the heir to dispose of his property at an inadequate price. In cases of this nature, it would be only equitable to allow a German who, due to local exigencies, had acquired a new nationality to retain his German nationality. ${ }^{28}$

${ }^{20}$ Verhandlungen des Reichstags. XIII. Legislaturperiode. I. Session. Stenographische Berichte. 13. Sitzung, 250.

${ }^{2}$ A similar doctrine seems to have been favored in our law. Kent says in his Commentaries, II, 75:

"An American citizen may obtain a foreign domicile, which will impress upon him a national character for commercial purposes in like manner as if he were a subject of the government under which he resided, and yet without losing on that account his original character, or ceasing to be bound by the allegiance due to the country of his origin."

${ }^{23}$ Bericht der 6. Kommission zur Vorberatung der Entwirfe vom 24. Aprit, 1913. Verhandlungen des Reichstags. XIII. Legislaturperiode. I. Session I9I2-13. Anlagen. Drucksache Nr. 962. p. I44I. 
In the report on the second reading of the bill in committee it was again stated, still more definitely, as the unanimous opinion of the committee, that the provisions of Section 25 of the new law would deprive any German of his German nationality immediately upon the voluntary acquisition of any foreign nationality whatsoever, regardless of treaty. The Bundesrat's representative concurred in this interpretation and asserted that there was no conflict between Section 25 and the provisions of the Bancroft Treaties which were reaffirmed in Section $36 .{ }^{29}$

Should a German subject desire to become a naturalized citizen in a foreign country and at the same time remain a German subject, the realization of such desire would depend entirely upon the discretion of the German authorities acting upon the individual's application to retain German nationality. The authorities to whom such petition is to be made must examine whether or not conflicts are likely to arise from granting such permission, and since dual allegiance is looked upon with disapproval, as pointed out above, a favorable consideration of such application would naturally, it seems, be very exceptional. To be apprised of the attitude of foreign governments on this question the co-operation of the German consuls is provided. The latter must express an opinion on the opportuneness of giving permission to retain German nationality to petitioners from their respective districts. ${ }^{30}$

The law provides a further check on these petitions by prohibiting entirely the grant of permission in cases where such dual nationality might cause controversies and complications with foreign governments, and gives the Imperial Government an effective supervision of all petitions for retention of German nationality in paragraph 3 of Section 25 , by providing that:

"The Imperial Chancellor with the consent of the Bundesrat may order that persons who wish to acquire nationality in a particular foreign country, shall not be granted the consent provided for in paragraph 2."

In the explanations accompanying the bill when introduced in the Reichstag it was said with reference to the above cited paragraph that whenever the political interests of the empire might demand it, the Imperial Chancellor should prevent the retention of German nationality by Germans who acquire the nationality of a foreign country, and that such limitation would especially apply to applicants in countries which require prospective citizens to renounce allegiance to their former country. ${ }^{32}$ This view was also expressed by the Bundesrat's repre-

\footnotetext{
${ }^{20} \mathrm{Ibid}$. $\mathrm{I456}$; as to Bancroft treaties see note 47 post.

${ }^{80}$ As to the procedure in such petitions see v. Keller und Trautmann, $a p$. cit. 294-295.

${ }^{31}$ Entwirrfe nebst Begrïndung, supra, 29.
} 
sentative during the discussions on the bill in the Reichstag committee..$^{82}$

So far as can be ascertained, the Imperial Chancellor has not, as yet, by formal promulgation announced the countries where the retẹntion of German nationality is not possible upon the acquisition of the new nationality.

The question of dual nationality as proclaimed in the German law, approached in the light of the legislative material analyzed in the foregoing paragraphs, finds a ready and satisfactory solution so far as the United States is concerned, and leaves hardly any doubt as to the full status as an American citizen of a German who has duly acquired American naturalization.

The consensus of opinion of German publicists ${ }^{33}$ with respect to the

\begin{abstract}
${ }^{32}$ Bericht der 6. Kommission, supra, I44I.
* See Romen, Reichs- und Staatsangehörigkeitsgesetz vom 22. Juli ror3 (1913) 100, 102, I42; Meyer, Reichs- und Staatsangehörigkeitsgesetz (1913) 169-172, 202; Cahn, Reichs- und Staatsangehörigkeitsgesetz (I914) I35, I36-137, I63; v. Keller und Trautmann, op. cit. 237-295; Cahn, La Loi Allemande sur la Nationalité, son Passé, son Présent, son Avenir (9 Revue de Droit International Prvé (Lapradelle, 1913) 335); Seeger, Das neue Reichs- und Staatsangehörigkeitsgesetz (42 JURISTISCHE WOCHENSCHRIFT, 95I); Lifschütz, Vergleichende Betrachtung der Staatsangehörigkeitsgesetze vam $I$. Juli I870 und vom 22. Juli I9I3 (33 ARCHIV DES ÖFFENTLICHEN RECETS (Laband, I915) 155); Blüher, Das neue Reichs- und Staatsangehörigkeitsgesetz (18 DeUTSCHE JURISTENzEITUNG, 890-893); Nelte in his article Die durch das 'Reichs- und Staatsangehörigkeitsgesetz' vom 23. Juli 1913 herbeigefiihrten Aenderungen des bestehenden Rechtszustandes (32 ARCHIV DES OfFentLichen RecHis (Laband) 22-36, esp. 33) says that loss of German nationality through acquisition of a non-German nationality occurs only if such acquisition is based upon the exercise of the will of the German.
\end{abstract}

There is also an article by Weil, La Nationalite dans les Rapports de l'Allemagne avec les Etats Unis et les Traités Bancroft (44 JourNaL DU DROIT INTERNATIONAL (Clunet, I9I7) 424-435, 899-910) in which the author discusses the loss of German nationality under the former and the present law. With reference to the retention of German nationality in accordance with s. 25, par. 2, he thinks (908-909) that German nationality cannot be preserved so far as the United States is concerned. A similar view is expressed in the same author's article La Double Nationalité en Droit Allemand avant et après la Loi du 22 Juillet 1913 (12 Revue DE DroIr International Privé (Lapradelle, I9i6) I42158, esp. I47, 152); see also his article Ambiguité de la Dénationalisation Allemande (43 Journal DU Drort InTERnationad (Clunet, 1916) 69 seq.). Another review of the German law (9 Revue DE Droit International Prive (Lapradelle, I913) 962-969) calls the provision of s. 25 a fraud, and says with reference to the United States that the naturalized individual of German origin commits perjury and the consul accepting the application for the retention of German nationality is his accomplice. This statement would seem to have no foundation in fact or law; while the author cites the Report of the Reichstag Committee, he has apparently omitted the reference to the United States. See also Pillet, $D \dot{u}$ Charactère Politique de la Notion de Nationalité (I2 RevUe DE DroIt INTERNational Prvé (Lapradelle, 19I6) I4-33), especially his reference to the German law and the Bancroft treaties $(27,28)$; Haennig, Une Fourberie Allemande. La Loi Delbrïck (I9I5). 
application of Section 25 of the law is that, although paragraph 2 of this section would permit, in a specific class of cases, the retention of German nationality, a German subject loses his German nationality ipso jure upon the acquisition of American citizenship for the simple reason that the conferring of the American national character is conditioned upon the unequivocal renunciation, in definite words, of any prior allegiance by taking the oath of allegiance in a formal court proceeding. ${ }^{34}$ The retention of German nationality would, therefore, be inconsistent with the idea and legal conception of American naturalization and would create an anomaly. After passing through the crucible of naturalization the individual is no longer a German, but an American.

American writers take the same view. Richard W. Flournoy, Jr., in discussing the question of dual nationality as involved in Section 25, paragraph 2, says:

"According to this provision [s. 25] a German residing in a foreign land may acquire naturalization therein without giving up his German nationality unless the laws of that country require the renunciation of the prior allegiance. This provision is apparently intended for the benefit of Germans residing in foreign lands which extend the franchise, the right to hold real property, etc., only to their citizens."35 And again. "This provision [s. 25] can have no application to Germans who are naturalized as citizens of the United States, since it is a specific requirement of our naturalization law that an alien who applies for naturalization must expressly renounce allegiance to all other sovereignties, and particularly by name to the sovereignty to which he at the time owes allegiance."36

Edwin M. Borchard comments on the German law as follows: "The new German law of nationality of I9I3 apparently sanctions such conflicts [arising from a dual nationality] by providing that a German residing in a foreign country may acquire naturalization therein without giving up his German nationality unless the laws of that country (as is the case in the United States) require the renunciation of the prior allegiance."st

A brief reference, at least, to Section I3 of the German law under discussion should be made here, although few of the critics of Section 25 have called attention to that earlier section, which in greater degree than Section 25 would seem to sanction and favor the principle of

\footnotetext{
st As to naturalization proceedings see below.

"Flournoy, Observations on the new German Law of Nationality, 8 Asr. Jour. INT. LAW (IgI4) 480.

${ }^{\circ} \mathrm{Ibid} .48 \mathrm{I}$; the same view is also expressed in his article in the NEW YoRK TIMes, note 5, ante; see also 9 AMr. Jour. INT. LAw (I9I5) 939-942.

${ }^{37}$ Borchard, The Diplomatic Protection of Citizens Abroad (19r5) 576, 584, 685, note 5 ; see also Mattern, Paragraph 25 of the New German Citizenship Law, 204 NoRre AM. REv. 856-868, explaining the correct meaning of the German law by drawing comparisons with the provisions in foreign naturalization laws, especially in the British Act of 1870 .
} 
dual allegiance. If any criticism is justifiable, it might be applied to the provision embodied in the following section:

"Section I3. A former German who has not settled in Germany, may on his application be naturalized (repatriated) by the Federal State to which he formerly belonged, provided he fulfills the requirements of Section 8, paragraph I, Nos. I, $2:^{38}$ the same applies to the child or adopted child of a former German. The Imperial Chancellor must be informed prior to the naturalization (repatriation); naturalization (repatriation) does not take place if he raises objections."

According to the law ${ }^{39}$ previously in force only those Germans who had lost their nationality through ten years' continuous absence abroad and without having acquired another nationality could be repatriated by their former home state without having taken up residence there. In all other cases of loss of nationality residence in the home state and the fulfillment of other conditions ${ }^{40}$ was formerly required. Thus, a great number of individuals whose retention as German subjects was most desirable from the German government's standpoint were precluded from redintegration because their calling and employment prevented them from resuming residence in Germany. Section $x_{3}$ of the new law of nationality, the most important in the whole law, grew out of and fulfilled this desire, frequently voiced in the Reichstag: the repatriation of former Germans abroad. It provides that such repatriation does not require settling in Germany, that not only former Germans who have become heimatlos-having lost German nationality and not having acquired any other nationality-but also their children and those who have become nationals of other countries. The significance and import of these provisions call for a brief explanation.

The Bundesrat's representative in commenting on Section 13 during the first reading of the government's bill in the Reichstag committee said that the mode of repatriation of persons "without nationality" (heimatlos) as set forth in this section would be favored in all cases where individuals abroad had been of great service to Germany. This included, first of all, representatives and agents of German business houses; furthermore, members of German communities in Palestine, missionaries, and those who had fostered German interests and extended German influence through German societies, and maintained

\footnotetext{
${ }^{2}$ Sec. 8, par. I.

"An alien who has settled in Germany may on his application be naturalized by the Federal State within whose territory such settlement has taken place-

"I. If, according to the laws of his former home State he is legally competent, or would be legally competent according to the laws of Germany, or if the application is made in accordance with s. 7 , par. 2, sentence 2 , by his legal guardian or with the latter's consent.

"2. If he has led an irreproachable life."

$\rightarrow$ See s. 2I, par. 4 of Law of June I, I87o.

Ibid. s. 8.
} 
and supported German churches or schools. Of course, Section I3 was not intended to vitiate genuine facts on which a loss of German nationality had been predicated, and especially in cases where individuals had lost their nationality on account of noncompliance with military obligations, or where they had without good reason acquired a foreign nationality. ${ }^{41}$ Section ${ } 3$ does not confer a right to repatriation, and the application may be refused without stating reasons therefor. A very careful examination is to be made of an application by a person who has obtained foreign naturalization by reason of the fact that in such a case conflicts growing out of dual allegiance must be expected. Great consideration must be paid to the fact whether or not the applicant had acquired foreign naturalization of his own free will and volition, and the deciding factor should be whether or not the repatriation would cause loss of his present nationality. If he would not by repatriation lose it according to the law of the naturalizing country, repatriation will - not be granted. The Imperial Chancellor passes upon the application. ${ }^{42}$

\section{II}

The foregoing deductions have shown, it is believed, that Section 25 of the German law of nationality does not admit dual nationality in general, and not at all so far as the United States is concerned, or that it affects in any way the American citizenship of individuals of German origin. This alone would appear sufficient to make clear the interpretation given in Germany to Section 25. Yet a study of other parts of the same law would seem to remove all doubt and to preclude false interpretations.

In drafting the law, the Bundesrat thought of the probability that the lack of a provision relating to the applicability of existing treaties might give rise to a question as to their further validity. ${ }^{43}$ To prevent all doubt, it is set forth in Section 36 of the law that existing treaties ${ }^{44}$

\footnotetext{
12 Begruendung, supra, 16; Bericht der 6. Kommission, supra, 1433 .

- See extensive commentary by v. Keller und Trautmann, op. cit. I57-165; see also Meyer, op. cit. II9-r23; Romen, op. cit. 59-63; Cahn, op. cit. 79-80; Nelte, op. cit. 30 . These writers maintain that such repatriation is not possible where conflicts with foreign countries are likely to arise. Also the provision in s. 33, par. 2, that "direct Imperial nationality (unmittelbare Reichsangehörig$k e i t)$ may be granted to a former German, who has not taken up residence within the German Empire," should be read in the light of the above explanations.

See Begründung, supra, 33.

"Naturalization Convention of Feb. 22, 1868, between the North German Union and the United States; similar treaties with the other German States; see Treaties, Conventions, etc., between the United States of America and other Powers, I776-1909 (6rst Cong., 2d Sess. Sen. Doc. No. 357) 53-55 (Baden); 60-63 (Bavaria); 949-95I (Hesse); I298-1299 (North German Union); 1895-
} 
are not affected by the law. Any inaccurate interpretation which uninformed publicists may have made of Section 25, the literal words of which, it must be conceded, do give rise to possible ambiguity, must be corrected by an examination of the legislative material upon which the section was based, and, beyond any possible room for doubt, by the provisions of Section 36 .

Some of these publicists, who have probably not been in a position to give the matter careful study, appear entirely to have overlooked the existence of the Bancroft treaties, the stipulations of which govern the naturalization of German subjects in this country, and which are applicable regardless of the provisions of the German statute, even if it bore the erroneous interpretation ascribed to it.

It is not intended to discuss in detail the engagements embraced in these treaties or their scope, but it appears desirable to undertake a brief survey of the conditions which brought about their conclusion, and to point out their relation to the present German law of nationality.

I898 (Württemberg). The treaties are the only instances before the enactment of the present law of nationality where Germany recognized the principle that naturalization in a foreign country effects loss of German nationality. "Prussia was the first of the European States to acknowledge the American principle of freedom of naturalization and denationalization" (Seward, Travels Around the World (I873) 7II). No other treaty of this sort has ever been concluded with any other foreign country by the German government. The treaty of Amity, Commerce and Navigation with Persia of June II, 1873 (Reichsgesetzblatt $1873,35 \mathrm{I}$ ), obligated the two contracting parties in Art. 17 to grant naturalization to persons only after permission of the respective governments had been obtained. The Treaties of Amity, Commerce, Navigation, and Consular Conventions with Guatemala of Sept. 20, I88r (Reichsgesetzblatt I888, 238), Nicaragua of Feb. 4, I8g6 (Reichsgesetzblatt 1897, I7r), Honduras of Dec. 12, I887 (Reichsgesetzblatt 1888,262 ), and Bolivia of July 22, 1908 (Reichsgesetzblatt 1910, 507), do not refer to naturalization of the respective nationals.

The conclusion of the Bancroft treaties had such an effect upon other governments that they, upon the initiative of the United States, entered into similar naturalization treaties. The text of these conventions may be found in Treaties, Conventions, etc., op. cit., in the volume indicated below. It is stipulated in such conventions that either after a continuous residence of five years coupled with naturalization, or upon voluntary naturalization according to law, the former citizens of the one contracting party should be regarded as citizens of the other. The countries with which the United States has concluded such conventions are the following:

Argentina, Aug. 9, I909, not ratified (III, 343) ; Austria, Sept. 20, I870 (I, 45); Belgium, Nov. I6, I868 (I, 80); Brazil, April 27, 1908 (Treaty Series, No. 547); Costa Rica, June Io, IgII (Treaties Series, No. 570) ; Denmark, July 20, I872 ( $I, 387$ ); Ecuador, May 6, I872 (I, 434), abrogated upon notice by Ecuador Aug. 25, 1892; Great Britain, May 13, I870 (I, 69I) ; Haiti, March 22, Ig02 (I, 939); Honduras, June 23, I908 (I, 958); Mexico, July Io, I868 (I, II32); Nicaragtia, Dec. 7, Ig08 (Treaty Series, No. 566, 567); Peru, Oct. I5, Ig07 (II, I449); Portugal, May 7, I908 (II, I468); Salvador, March I4, I908 (II, 1570); Sweden and Norway, May 26, I869 (II, I758); Uruguay, Aug. ro, I908 (II, I829). 
Whether or not the conventions are suspended during the period of the war will not be considered. It would seem, however, that a treaty of this kind remains in operation. ${ }^{45}$

The Bancroft treaties were the result of a long standing controversy over the treatment accorded naturalized Americans of German origin upon their return to Germany. The United States Government contended that the acquisition of American citizenship cancelled all obligations owed under the former allegiance, and declared the practice of the German states which, according to their laws, regarded such naturalized American citizens as still their subjects for purposes of military service or held them responsible for the consequences of evading such service by emigration, as inconsistent with the principle of the absolute right of expatriation. The resulting conflicts led to lively discussions extending over many years and made it advisable to reach an amicable understanding by formal conventions. Our Civil War (I86I-I865) and the Austro-Prussian War (I866) prolonged the negotiations, and it was not until $\mathrm{I} 868$ that the first treaty was signed by Prussia on behalf of the North German Union. This was due to the untiring efforts of George Bancroft, then United States Minister to Prussia, and to the frankness of Bismarck, who expressed thereby the Prussian government's aversion to the doctrine of dual allegiance. The other German states followed; Great Britain fell in line in May, 1870, and Austria in September, I870. American diplomacy had scored a decided victory upon the ratification of the treaty, which was frankly conceded in Prussia. The German states received nothing in exchange for their engagements, for, although in form the treaty rests upon reciprocity, the advantages are all on the side of the United States. Criticism was, therefore, soon directed against the Prussian government for its action, and a demand made for the revocation of the treaty. ${ }^{48}$

"As to effect of war on treaties see Crandall, Treaties, Their Making and Enforcement (2d ed.) s. I8; also Society, etc. v. New Haven (1823) 8 Wheat 465.

${ }^{46}$ As to the diplomatic correspondence concerning the controversy and the negotiations for the treaties see the documents in the following collections: Message of the President of the United States communicating, in Compliance with Resolutions of the Senate Information relative to the Compulsory Enlistment of American Citizens in the Army of Prussia, etc. (Sen. Ex. Doc. No. 38, 36 th Cong. Ist Sess), containing the diplomatic correspondence with Prussia from I840 to I860; Message of the President of the United States and Correspondence between the Government of the United States and the Government of France and Prussia, touching Military Service asserted by those Governments with reference to Persons born in those Countries, but who have since become Naturalized under the Lazes of the United States (Sen. Ex. Doc. No. 4, 40th Cong., Ist Sess., 53-I44), containing the correspondence with the Prussian Government during I858-66; Message of the President of the United States and Accompanying Documents (H. 'Ex. Doc. No. I, 40th Cong., 2d Sess. 582-600), giving the diplomatic correspondence of 1867 ; Papers relating to Foreign 
The principles expounded in these treaties are the same, although the language employed varies slightly. It will suffice for our purposes to outline briefly the treaty with the North German Union. ${ }^{47}$

Article I states the conditions upon which change of allegiance must be recognized; Article II refers to punishment for offenses committed

Affairs, I868, II, 40-56, containing the diplomatic correspondence of 1867 and I868 leading to the conclusion of the conventions; see also 3 Moore, op. cit. s. 390-394 as to diplomatic correspondence and application of the treaties, Kapp, op. cit. Vol. 35, p. 524-534, 660-683; Vol. 36, p. I89-227; v. Martitz, op. cit. 820-821, 824-828, 833; also Bendix, Fahnenflucht und Verletzung der Wehrpflict durch Auswanderung (1906) (Staats- und Völkerrechtliche Abhandlungen No. 5).

${ }^{17}$ Bendix, op. cit. 103-104, I23 seq., who claims that upon the establishment of the German Empire in 187I the naturalization treaties concluded with the different German states became obsolete except the treaty with the North German Union. This view has not been shared either by the German or the United States Government: see Crandall, op. cit. s. 179, especially the cases cited there in footnote 23.-Text of the Naturalization Convention of Feb. 22, 1868, concluded with the North German Union (2 U. S. Treaties, etc., I298):

"Article I. Citizens of the North German Confederation, who become naturalized citizens of the United States of America and shall have resided uninterruptedly within the United States five years, shall be held by the North German Confederation to be American citizens, and shall be treated as such.

"Reciprocally, citizens of the United States of America who become naturalized citizens of the North German Confederation, and shall have resided uninterruptedly within North Germany five years, shall be held by the United States ruptedly within North Germany five years, shated as such. The declaration of an intention to become a citizen of the one or the other country has not for either party the effect of naturalization.

"This article shall apply as well to those already naturalized in either country as those hereafter naturalized.

"Article II. A naturalized citizen of the one party on return to the territory of the other party remains liable to trial and punishment for an action punishable by the laws of his original country and committed before his emigration; saving, always, the limitations established by the laws of his original country.

"Article III. The convention for the mutual delivery of criminals, fugitives from justice, in certain cases, concluded between the United States on the one part and Prussia and other States of Germany on the other part, the sixteenth day of June, one thousand eight hundred and fifty-two, is hereby extended to all the States of the North German Confederation.

"Article IV. If a German naturalized in America renews his residence in North Germany, without the intent to return to America, he shall be held to have renounced his naturalization in the United States. Reciprocally, if an American naturalized in North Germany renews his residence in the United States, without the intent to return to North Germany, he shall be held to have renounced his naturalization in North Germany. The intent not to return may be held to exist when the person naturalized in the one country resides more than two years in the other country.

"Article V. The present convention shall go into effect immediately on the exchange of ratifications, and shall continue in force for ten years. If neither party shall have given to the other six months' previous notice of its intention then to terminate the same, it shall further remain in force until the end of twelve months after either of the contracting parties shall have given notice to the other of such intention.

"Article VI. The preseni convention shall be ratified by the President, by and with the advice and consent of the Senate of the United States, and by His Majesty the King of Prussia, in the name of the North German Confederation; and the ratifications shall be exchanged at Berlin within six months from the date hereof.

"In faith whereof, the Plenipotentiaries have signed and sealed this convention. Berlin, the $22 \mathrm{~d}$ of February, 1868." 
prior to emigration; Article III reaffirms existing extradition treaties, and Article IV deals with repatriation. We may confine our attention to Article I. It sets forth, as pointed out above, the maxim that nationals of the North German Union who have become naturalized citizens of the United States and have resided there uninterruptedly five years shall be regarded and treated by the former as citizens-of the latter, and vice versa.

This stipulation declares that the North German Union must regard its nationals who have emigrated to the United States and have acquired American citizenship as American citizens and no longer as subjects of the states comprising the North German Union, provided such individuals have resided within the jurisdiction of the United States continuously for five years.

Since the new German law went into effect, loss of German nationality is no longer consequent upon mere length of residence abroad. The loss occurs immediately, as we have seen above, upon the acquisition of a foreign nationality. The provision of the law goes further than the stipulation in the treaties; it does away with the condition as to the period of foreign residence, thus constituting a modification of the treaty stipulation and an apparent conflict.

Reference to the Reichstag committee report will again elucidate the matter. It is there stated in answer to a question regarding the relation of the treaties to Section 25 of the new law, that the German states were quite at liberty to regard any German residing in the United States as having lost his German nationality for specific reasons before the expiration of five years. The loss of this nationality might under the new law of nationality (Section 25, paragraph I) occur regardless of the length of his residence abroad.

The relation of Section 25, paragraph I of the German law to the Bancroft treaties is analogous to the situation which was created by our law of March 2, 1907.48 According to Section 2 of this act, an American loses his citizenship upon his naturalization in a foreign country. The question never appears to have been raised whether such provision would conflict with the engagements in the Bancroft treaties. ${ }^{49}$

Both the German as well as the American law are, with respect to the foreign country of naturalization, more lenient than the treaties. Whereas the treaties require naturalization plus five years' residence abroad as a prerequisite to the recognition of a loss of original nationality, the statute requires merely naturalization. The modification does not, therefore, create conflicts, but rather tends to avoid them.

${ }^{4} 34$ Stat. L. 1228. The act makes an unfortunate distinction between native and naturalized American citizens.

-As to effect of legislation on existing treaties see Crandall, op. cit. s. I86; also notes in II Compiled Statutes Annotated (I9I6) I3884-85. 
Under the United States naturalization laws, however, five years' residence is a condition precedent to naturalization, ${ }^{50}$ so that in practice a German does not lose his nationality until after the expiration of this period, and the treaty stipulation remains in fact still applicable. Yet there are a few unimportant exceptions to the requirement of residence.

Shorter terms are allowed to aliens of at least twenty-one years of age, who, after an honorable discharge from the United States Army, the regular or volunteer forces, may be admitted to citizenship upon proof of only one year of residence. ${ }^{51}$ Also, aliens, qualified under existing law to become American citizens, who have been honorably discharged from the United States Navy, Marine Corps, or Revenue Cutter Service after one enlistment of four years may be admitted to citizenship without proof of residence, ${ }^{52}$ or sailors in the merchant marine after three years' service on an American vessel. ${ }^{53}$

To these exceptions the Bancroft treaties do not apply; the German states were not bound before the adoption of the new law of nationality to recognize naturalization granted upon a term of less than five years' residence. Nor did the treaties extend to German subjects from Alsace-Lorraine and the German colonies, ${ }^{54}$ for these territories never constituted a part of any one of the states which have concluded the naturalization conventions. The benefit of the Bancroft treaties does not, therefore, extend to individuals from such parts of the German Empire nor to German subjects who have acquired American citizenship in less than five years.

This embarrassing defect in the treaties, as has been pointed out, is now removed and remedied, and individuals coming under the exceptions just stated are placed in a more advantageous position, in that they are put on an equal footing with other German subjects. They will be regarded by the German government as having lost their German nationality immediately upon the acquisition of American citizenship regardless of the period of their residence in the United States.

This is not the place to take up the other provisions of the treaties. It may, however, be pointed out that the naturalization treaties do not extend to the individual immunity against any pre-existing claim of his native country. The former national still remains subject, upon his return to his country of origin, to punishment for offenses committed prior to his emigration, particularly for the evasion of military service,

${ }^{30}$ Sec. 4 of Act of June 29, I906, 34 Stat. I. 596.

${ }_{51}$ Rev. Stat. s. 2166, Act of July I7, 1862, ch. 200, s. 21; I2 Stat. L. 577.

act June 30, 1914, ch. 130, $3^{8}$ Stat. L. 395. This act has probably superseded the Act of July 26, I894, ch. 165, 28 Stat. L. I24, providing that aliens honorably discharged from service in the Navy or Marine Corps after one term of enlistment may become American citizens.

Rev. Stat. s. 2174, Act of June 7, 1872, ch. 322, s. 29; I7 Stat. L. 268.

See 3 Moore, op. cit. s. 392; Bendix, op. cit. I9I. 
if such liability was an existing or accrued and not merely a future obligation, unless lapse of time bars the operation of the law..$^{55}$

The war has also created a new problem in this respect. A German imperial ordinance ${ }^{56}$ issued shortly after the outbreak of the war denies release from German nationality to all persons liable to military service. How will those persons of German origin who have become naturalized after the issuance of this ordinance be treated upon their return to Germany? Will the United States government protect them inasmuch as our own law contains an analogous provision, ${ }^{57}$ that, namely, prohibiting any American citizen to expatriate himself when this country is at war?

That the position of the United States with regard to renunciation

\footnotetext{
* See Borchard, op. cit. 549; v. Keller und Trautmann, op. cit. 297-315, notes to s. 26 of the law relating to punishment for evasion of military service and desertion.

${ }^{83}$ Law of Aug. 3, I9I4, s. I, Reichs-Gesetzblatt I914, 323.

${ }^{57}$ Act March 3, Ig07, s. 2, 34 Stat. L. r228; see also In Re Look Tin Sing (r884) 2x Fed. 905; 9 Op. Atty. Gen. 63 (I857). A strict construction of the provision of s. 2 of the Act of March 2, I907, that "no American citizen shall be allowed to expatriate himself when this country is at war" apparently affects the marriage of an American woman to an alien during time of war. Sec. 3 of the act is declaratory of the common law and provides "that any American woman who marries a foreigner shall take the nationality of her husband." See also recent case of MacKenzie v. Hare (1915) 239 U. S. 299; aff. (Igr3) 165 Cal. 776. The question arises whether or not $s$. 2 suspends the application of s. 3. If so, an American woman retains upon such marriage her American citizenship; her legal status as an American citizen remains unchanged, and her constitutional rights and privileges are not curtailed. If she resides in this country she may, where a state statute has conferred upon her the franchise, exercise such right. Upon such a woman would, however, also devolve all the duties of citizenship including those incident to a state of war. If her acts should be incompatible with her American allegiance, she might be guilty of treason, while such acts might only constitute a crime defined under the Espionage Act if she had taken the nationality of her husband upon marriage. Obviously, the statute in question results in the conferring of a dual nationalitythe unhappy status which the United States Government has always combated. Suppose the woman having married a friendly alien should go to the country of her husband, or the woman has married such alien abroad, the laws of that country would probably not regard her as an American citizen, but as one of its own citizens. Would the United States Government be in a position to extend protection to such a woman? Suppose the woman should marry an enemy alien, she would, under the law, be an enemy of her husband; certain restrictions placed upon the intercourse with enemy aliens would also apply to her, while at the same time she would be exempt from the limitations placed upon enemy aliens. Would the declaration of peace as a matter of course change such a woman's status from that of an American citizen to that of a citizen or subject of her husband's country, or would some definite act be necessary to effect the change of nationality? Would the United States Government grant such a woman a passport to travel abroad? These are a few of the possibilities that readily present themselves as being involved in the conflict of the provisions of the Act of March 2, I907.
} 
of allegiance is unmistakably very decided, becomes evident from the rigid requirements which must be fulfilled before an alien can be naturalized. ${ }^{58}$

The Naturalization Act ${ }^{59}$ provides that an alien before filing his declaration of intention to become a citizen

"shall declare on oath before the clerk of any court authorized by this act to naturalize aliens . . . two years at least prior to his admission, and after he has reached the age of I8 years, that it is bona fide his intention to become a citizen of the United States, and to renounce forever all allegiance and fidelity to any foreign prince, potentate, state, or sovereignty, and particularly, by name, to the prince, potentate, state, or sovereignty of which the alien may be at the time a citizen or subject."

And accordingly, the alien's declaration of intention reads :

“. . It is my bona fide intention to renounce forever all allegiance and fidelity to any foreign prince, potentate, state, or sovereignty, and particularly [in the case of a German] to William II, German Emperor, ${ }^{61}$ of whom I am now a subject ..."

As to naturalization proceedings see Van Dyne, op. cit.; Wise, $A$ Treatise on American Citizenship (1906).

Act June 29, 1906, 34 Stat. L. 596.

${ }^{\infty}$ Ibid. s. 4, par. I.

The form of the oath is technically incorrect. The alien German petitioner owes allegiance to the sovereign of his particular home state in the German Empire. No allegiance is owed to the German Emperor except in the case of an individual from Alsace-Lorraine, or of a person having acquired German nationality in the German colonies, or of a person having obtained imperial nationality in accordance with s. 33-35 of the present law. German nationality is primarily based upon the nationality acquired in one of the Federal states by birth, legitimation, marriage or naturalization (s. 3-16 of the law of nationality), and with the acquisition of the state nationality, imperial nationality is automatically conferred. An individual does not need special naturalization to obtain the imperial nationality. He is a part of the empire as a member of his state, he cannot be a German national without being a member of a particular state. The contrary is true in this country where a person becomes a citizen of a particular state through residence after the acquisition of American citizenship; the federal citizenship is the primary relationship. A German may change his state nationality without affecting thereby his German nationality; the latter is lost when he ceases to be a member of a particular federal state (see Laband, Das Staatsrecht des Deutschen Reiches (5th ed. I9II) I43; Fischbach, Das Öffentliche Recht des Reichslandes Elsass Lothringen, 26 Das Öffentliche Recht der Gegenwart (Igr4) 20, 26-27). This primary relationship of a German subject to the sovereign of his home state is also expressed when a German wishes to expatriate himself by a release from German nationality. Such release, which is granted by his home state, in accordance with the provisions of s. I8-24 of the present nationality law, bears the following language: "When this document is delivered . . . [name, etc., of person] loses the nationality of . . . [Prussia, Bavaria, Saxony as the case may be] and thereby German nationality" (see v. Keller und Trautmann, op. cit. 368). The same principle is proclaimed when the German recruit takes the oath of allegiance 
When the alien files his petition for naturalization, such petition shall set forth

"that it is his intention to become a citizen of the United States and to renounce absolutely and forever all allegiance and fidelity to any foreign prince, potentate, state, or sovereignty, and particularly by name to the prince, potentate, state, or sovereignty, of which he at the time of filing of his petition may be a citizen or subject . . ."

In the petition for naturalization the alien deposes:

“. . . I am attached to the principles of the Constitution of the United States and it is my intention to become a citizen of the United States and to renounce absolutely and forever all allegiance and fidelity to any foreign prince, potentate, state, or sovereignty, and particularly [in the case of a German] to William II, German Emperor, of whom at the time I am a subject ..."

At the final hearing upon the alien's petition for naturalization before a judge, the petitioner

"shall before he is admitted to citizenship, declare on oath in open court that he will support the Constitution of the United States, and that he absolutely and entirely renounces and abjures all allegiance and fidelity to any foreign prince, potentate, state, or sovereignty, and particularly by name to the prince, potentate, state, or sovereignty of which he was before a citizen or subject; that he will support and defend the Constitution and laws of the United States against all

(Fahneneid). He first takes this oath to the sovereign in whose jurisdiction the contingent is located, and then he pledges obedience to the commander-inchief, the German emperor (see Endres, Karl, Deutsche Wehrverfassung (Ig08) I5, I9; also Gronow und Soh1, Militärstrafrecht (I906) 238-242). The form of the oath of allegiance in our naturalization proceedings should be changed by inserting the name of the sovereign of the petitioners' home state. The present inaccuracy does not seem to be of so serious a nature as to invalidate the naturalization certificate, because allegiance is sworn off to any sovereign to whom the petitioner might owe allegiance. Yet, if the question should be raised and the assertion be made that the former allegiance was never sworn off, advantage might be taken of the technically incorrect form, and the court might sustain the contention, especially where the question of citizenship will be the deciding factor, as, $e$. $g$. , in the case of treason or under one of the present war measures. Cf., however, In Re Denny (IgI7) 240 Fed. 845, where the question of mistake in the name of the sovereign whose allegiance the petitioner meant to abjure was decided. To quote the court:

"The only vitally necessary allegation in this connection is his explicit purpose to assume his new allegiance and to abjure his former sovereign, whatever he may suppose it to be. It would be an extreme scholastic technicality to suggest that, where an applicant has twice asserted his intention to become a citizen of the United States and to renounce his fealty to the sovereign of whom he was then a subject, any doubt could be cast upon that intention because he had by mistake named the wrong sovereign."

${ }^{2}$ Act of June 29, 1906, supra, 27.

${ }^{63}$ Ibid. s. 4, par. 2.

Ibid. s. 27. 
enemies, foreign and domestic, and bear true faith and allegiance to the same."

From the early case of John Philipp Knoche, who, after becoming a naturalized American citizen was, upon his return to Prussia, compelled to do military service, and whose petition to the American legation at Berlin for relief was denied on the ground that protection did not extend to naturalized American citizens when they returned to their native country, ${ }^{68}$ down to the latest rulings of the Department of State, ${ }^{67}$ the attitude of our government towards the question of dual allegiance has become more definite and certain. Mr. Moore best expresses the policy and practice of the government of the United States in the following passage:

"It is sometimes stated that double allegiance also exists where a person born in one country afterwards emigrates to and becomes a citizen of another country. That a person in such a situation may be a subject to the claims of allegiance in two countries, is in point of fact no doubt true; but in point of principle equally true that, when writers place such case under the head of double allegiance, they at least impliedly hold that the doctrine of voluntary expatriation, as maintained by the United States, is not well founded. . . . From the point of view of the doctrine of expatriation, as enunciated by the United States, the man who, voluntarily forsaking his original home and allegiance, acquires a new one, has thereafter but one allegiance-that of his adopted country."

Considering the American naturalization of an individual of German origin in the light of the German law of nationality, the accompanying legislative material, the commentaries on the statute, the provisions of the Bancroft treaties, and the practice and policy of the United States government, we must necessarily reach the conclusion that the alleged "infamous" provision in the Delbrück law finds no application to the naturalization of German subjects in the United States. There is no conflict between the German law and the Bancroft treaties, and the principles enunciated in the American and German law are in perfect accord and harmony. Both agree that, to quote from an instruction of July $8,1859^{69}$ by Secretary of State Lewis Cass to J. A. Wright, Minister to Prussia,

\footnotetext{
"s Ibid. s. 4, par. 3.

${ }^{\infty}$ See 3 Moore, op. cit. 564; Borchard, op. cit. 543 seq.

"Department of State, Diplomatic Correspondence with Belligerent Governments relating to Neutral Rights and Duties. European War, No. 3. Part XVI. The case of Frank Ghiloni involves, however, a slightly different principle. The petitioner was born in this country of Italian parents and was compelled by the Italian government to do military service. This government took the position that Ghiloni had exercised the right of election of nationality by being domiciled here at the time of attaining majority.

${ }^{\infty} 3$ Moore, Dig. of Int. Law 513-519.

Ibid. 574; see also the interesting article by Whelpley, Naturalized Americans, IO8 FORTNIGHTLY REV. 594-603.
} 
"the moment $a$ foreigner becomes naturalized his allegiance to his native country is severed forever. He experiences a new political birth. A broad and impassable line separates him from his native country."

\section{SUPPLEMENTAL NOTE}

The following is a list of provisions in the municipal law of foreign countries showing to what extent the right of expatriation, exercised when acquiring a new nationality by naturalization in a foreign country, is recognized by the native country. Regard should be paid, however, to the existence of naturalization treaties concluded between some of the countries, as such conventions affect the application of the municipal law. Unless otherwise indicated, expatriation through foreign naturalization may be regarded as recognized unconditionally by the particular native country.

Argentina. Ley de Ciudadania Argentina de Octubre 8 de 5869 , Titulo IV, Art. 8 (Registro Nacional, 1869. Tomo octavo, 292) (H. Doc. No. 326, 59th Cong. 2d Sess. 273). Political rights may not be exercised in the republic by former Argentine citizens naturalized in a foreign country.

Austria. There is no uniform law of nationality. The recognized principle that acquisition of foreign nationality causes loss of Austrian nationality is limited only in so far as persons of military age remain subject to military obligations. See 2 Mayerhofer, Handbuch für den politischen Verwaltungsdienst (I896) 918 seq., esp. 942.

BeIGIUM. Loi sur l'Acquisition et la Perte de la Nationalité du 8 Juin Igog, s. II.I (Servais et Mechecynck, Les Codes Belges (I912). II36).

Bolrvia. Constitución Politica, $r_{5}$ de Febrero de I880, Art. 35.I (Camera de Senadores. Constitución Politica del Estado (1912) 24) (H. Doc. No. 326, p. 288). Código Civil, Art. 9.I (Siles, Código Civil (1910) 10).

BraziL. Decreto N. 569 de 7 de Junho de I899. Art. I.I (Colleç̧ão das leis de I8g9 (I902) 2) (H. Doc. No. 326, p. 288). Constitução, Art. 7r, s. 2a (Tarquinio e Montenegro, Leis usales (1903) 2) (H. Doc. No. 326, p. 290).

Bulgaria. Law of Jan. 5-18, Ig08, and law of Dec. 8-2I, IgIr, C. V, Art. I7.I ; $2 \mathrm{I}$; see v. Keller und Trautmann, op. cit. 643. Permission of the government is required if military obligations have not been fulfilled; no Bulgarian national residing in Bulgaria may acquire a foreign nationality without the permission of the government.

CHrne. Constitución Política, C. III, s. 9.3 (Collectión de Códigos (I9ra) 9) (H. Doc. No. 326, p. 291).

ChINA. Law of nationality of Dec. 30, 19r4, s. I2.4, 5 par. 2 ; I3; I4; see 44 Journal DU DroIt International (Clunet) 770 . Permission of the Minister of the Interior is required. Such permission will not be given unless the applicant is 20 years old; if he is still liable to military service; if he is in active military or civil service; if he is under indictment for a criminal offense; if he is defendant in a civil action; if a judgment of a criminal or civil court is still unsatisfied; if bankruptcy proceedings against him are still pending; if taxes, fines, or other
debts are still owed by him.

Colombra. Constitución Pólítica, Art. 9 (Rodriguez, Constitución y Leyes Usuales (I913) 6) (H. Doc. No. 326, p. 292). Naturalization in a foreign
country is recognized when person resides there.

Costa Rica. Constitución Pollitica de I9I7, Art. 40.x (La Gaceta. Diario Oficial. I3 de Junio de 1917, 597). Ley de Extranjeria y Naturalizatión de 21 de Diciembre de I886, Art. 4.1 (Colección de las Disposiciones Legislativas y Administrativas (1887) 640) (H. Doc. No. 326, p. 296).

CuBa. Constitución de 21 de Febrero de Igor, Art. 7.I (I Colección Legislativa (Ig06) 7) (H. Doc. No. 326, p. 300). 
DeNMARK. Lov Nr. 42 af I9. Marts 1898 as amended by Lov Nr. 57 af 23. Marts 1908, s. 5.I (Samling af Love, Anordininger m. m. Afdeling A (I908) I06). Person desiring to become naturalized in a foreign country may, by royal decree, be released from Danish nationality. Such release will be granted on condition that petitioner becomes a national of a foreign country within a specified period.

Dominican Republic. Constitución, 20 de Marjo de I9o8, Art. 7, s. I (Gaceta Oficial. 2I de Marzo I908, No. 876). No Dominican may claim any other except Dominican nationality while temporarily or permanently residing within the Republic. Art. I3.5 and $\S \S$ of the proposed new constitution (Boletin Oficial de la Asamblea Constituijente, Noviembre de IgI6, año $I$, num. $I$, p. 6) declares that the rights of citizenship but not the nationality are lost by naturalization in another country.

Ecuador. Constitución Politica, 23 de Diciembre de 1906, Art. 14.2 (Registro Oficial, 24 de Diciembre de 1906,2224$)$.

France. Loi dû 26 Juin r889 sur la Nationalité, Art. I7.I (Tripier et Monnier, Les Codes Français (I912) 9) (H. Doc. No. 326, p. 318). Permission of the government is required if the person is liable to military service in the active army. See also recent case in Cour de Cassation, 8 Mars 19r3, Aff. Grandjean (Sirey, Recueil Général (rgr3) Bull. des Sommaires I, p. 77). Similar provisions apply to French colonies.-A bill introduced on Nov. II, I9I3 (Jouraral Officiel Sénat. Documents, Sess. Extr. I9r3. Annexe No. 404) proposed the following amendment to the above law:

"If a person is still liable to military service in the active army or the reserve, foreign naturalization or voluntary acquisition of foreign nationality shall not result in the loss of French nationality, unless authorized by the French government."

Greece. Civil Code of Oct. 29 (Nov. Io) 1856, Art. 23a, as amended by law No. I20 of Jan. 2 (I5) IgI4; see Gt. Brit. Par1. Pap. Misc. No. 4, I9I4 [Cd. 7362]. Foreign naturalization will be recognized, if permission of government was obtained. Such permission will not be granted if applicant has not fulfilled his military obligations, or if he is prosecuted criminally.

Great Britarn. Nationality and Status of Aliens Act, rgr4, s. I3-16 (4\& 5 Geo. V, ch. I7; 18 Chitty's Statutes (I9I5) 14-15). Loss of nationality does not discharge from obligations incurred while individual was still a British subject.

Guaterana. Ley de Extranjería en $2 x$ de Febrero de 1894 , Art. 8 (12 Recopilación de las Leyes (1893-94) 690) (H. Doc. No. 326, p. 432). Foreign nationality will only be recognized during person's residence abroad.

HaITr. Loi du 22 août 1907, Art. I7.I (Annuaire de Legislation (1908) 29). Constitútion de 1839, Art. 10.I (Ganthier, I Recueil des Lois et Actes de Républic d'Haiti de I887 à I904 (I907) 357) (H. Doc. No. 326, p. 430).

Honduras. Ley de Extranjería, 8 de Febrero de Igo6, Art. 1.4, 9, II (Codificación de 1906 ) (H. Doc. No. 326, p. 438). Hondurian nationals having acquired nationality in a foreign country must reside there in order to lose Hondurian nationality.

HuNGaRY. Gesetzartikel über den Erwerb und Verlust der ungarischen Staatsbürgerschaft, Dec. 20, 1879, s. 36, 20-30 (Landesgesetze des Jahres I879, $378,374-377$ ). Naturalization in a foreign country will be recognized if person has complied with the conditions relating to release from Hungarian nationality.

ITALY. Legge 13 Giugno roI2 sulla Cittadinanza Italiana, Art. 8 (II Leggi $e$ Decreti (I9I2) 1490). Acquisition of foreign nationality does not exempt from military obligations.

JAPAN. Law of nationality of March 15, 1916, Art. 17, 24, 20 bis. (10 Axs. JouR. INT. LAw, 367-368). Foreign naturalization will be recognized if person (age $17-40$ ) has complied with or is exempt from military obligations. 
LIECHTENSTEIN. Gesetz über die Erwerbung und den Verhust des liechtensteinischen Staatsbürgerrechts, 28 März I864, s. 8, Io (Liechtensteinisches Landes-Gesetzblatt 1864, No. 3). Individual may expatriate himself upon proof that he has satisfied his creditors, has fulfilled his military obligations, and has obtained foreign nationality.

Luxemburg. Code Civil, Art. I7.I (Ruppert, Code Civil (Ig03) 3).

Mexico. Ley de Extranjería y Naturalizacion de 28 de Mayo de 7886 , Art. 2, V; 6 (Ammario de Legislación y Jurisprudencia. Sección de Legislación anõ 1886, 420, 430) (H. Doc. No. 326, p. 454). Constitución Política de 5 de Febrero de I9I7, Art. 37.I (5 Diario Oficial. 5 de Febrero de I9I7, No. 30, p. I52) (I Mexican Review, Washington, D. C., No. 6, p. 5).

Monaco. Ordonnance du I3 Avril IgII sur la Nationalité, Art. I7.I (Code Civil Monaco, I913, 5).

NeTHERLANDS. Wet van $15 J_{\text {uli }}$ I9Io, houdende wijziging der wet van I2 December 1892 op het Nederlanderschap en het ingezetenschap, gewijzigd bij de wet van 8 Juli 1907 en bij de wet van Februari I9Io, Art. 7.I, 5.3 (Fruin, De Nederlandsche Wetboeken (1912) I693).

NICaragua. Constitución Politica, 2 de Diciembre de IgII, Art. Io.I (Com stitución Politica de la República de Nicaragua (I9I2) 8). Foreign naturalization of Nicaraguans is recognized only if acquired in other than Central American countries and only during residence there.

NoRway. Lov om norsk. Statsborgerret m. m., 2I April I888, s. 6.a (Norsk Loutidende 2den Afdeling ( 1888 ) 63) (H. Doc. No. 326, p. 474).

Panama. Constitución, 15 de Febrero de I904, Art. 7.I (Gaceta Oficial. Numero Extraordinario. I6 de Febrero de I904).

Paraguay. Constitución, is de Novembre de 1870 (2 Rodriguez, American Constitutions (I906) 390) (H. Doc. No. 326, p. 48r). Art. 40 has no provision as to loss of nationality by naturalization in a foreign country.

Persia. Law of Aug. 7, I894, Arts. 8, 9, ro (H. Doc. No. 326, pp. 484-485). A Persian subject may not acquire foreign nationality unless he has obtained the permission of the Shah. Permission will not be given if the applicant has ever been convicted of a crime by a Persian court; if he is under indictment for a criminal offense; if he is a fugitive from justice; if he is a deserter.; if he is in debt or seeking to escape his liabilities. Upon the return to Persia of any person who has acquired foreign nationality unauthorized and to whom any of the foregoing disabilities are applicable, such person will be regarded as a Persian subject. Even where a person is under no disability and has acquired foreign nationality without permission, he must dispose of his property situated in Persia, and upon his return he will be excluded from the country.

PERU. Constitución de Noviembre de r860, s. 41.3 (Leyes y Resoluciones el año de I860, 3) (H. Doc. No. 326, p. 483).

Portugal. Código Portuguez de Julho de 1867, Art. 22.I (Setima Edição Official (r907) 6) (H. Doc. No. 326, p. 487).

Roumania. Code Civil, Art. I7.a (Extraits de la Legislation de la Roumania (1889) 4) (H. Doc. No. 326, p. 49r).

Russia. There is no direct legal provision for the release from Russian allegiance of natural-born Russian subjects, such release depending entirely upon the will of the sovereign, which is not frequently exercised. There are, however, provisions for the release of naturalized Russian subjects.

A person above the age of 15 may be released only if he has complied with his military duties, or drawn a lot which frees him from military service (see Martens, Nouveau Recueil Général de Traités. ze Série, Tome I9 (I895) 6ro-61r) (H. Doc. No. 326, p. 495). An attempt to draft legal provisions for the expatriation of Russian subjects was commenced some years ago, but the result is not known. Art. 325 of the Criminal Code (see Glasenapp, Gesetzbuch der Criminal- 
und Correctionsstrafen (1892) ro2, also s. $326,327,328$ ) provides, however, that any voluntary emigration or unauthorized naturalization abroad or entering into foreign service will be regarded as a breach of allegiance and be punished by loss of civil and political rights and permanent exile from Russia (see Cahn, Reichsund Staatsangehörigkeitsgesetz vom 22. Juli I9I3 (I9I4) 53I ; For. Rel. (I895) II, II05; 3 Moore, Dig. of Int. Law, s. 453; Borchard, op. cit. s. 237). This provision is not contained in the Criminal Code of March 22, I903: see Bernstein, Das neue russische Strafgesetzbuch (Ig08).

The provisional government, established immediately after the outbreak of the revolution in March, 1917 , has apparently made no change in the law. It did not recognize the right of expatriation, for in its proclamation abolishing religious and political restrictions, the right of expatriation is not mentioned (see Bulletist of the Temporary Government, March 22, 1917). Therefore, the status of naturalized American citizens of Russian origin in relation to the Russian Government remains as it is set forth in the State Department's Circular of Jan. 9, I914, Notice to Americas Citizens formerly Subjects of Russia who contemplate returuing to that Country. According to this circular the United States Government regards itself absolved from the obligation to protect such American citizens while they remain in their native land.

San Salvador. Constitución, $r_{3}$ de Agosto de I886, Art. 53.3 (Rodriguez, op. cit. 269) (H. Doc. No. 326, p. 500). Ley de Extranjeria, 30 de Setiembre de I886, Art. 6.7 (Diario Oficial. I Nov. I886).

SERBIA. Decree of Jan. 20, I860 (see v. Keller und Trautmann, op. cit. 722) (H. Doc. No. 326, p. 502). A Serbian subject may change his nationality upon proof of naturalization in a foreign country and of the fulfilment of his obligations towards the state, his family, and other persons.

SiAk. Nationality law of April I0, Igr3 (Buddha year 2456) s. 5-10 (Gt. Brit. Parl. Pap. Misc. No. 8 (Igr3) [Cd. 7057]). Foreign naturalization will not be recognized if acquired without the Siamese government's authorization.

Spars. Código Civil, r888, Art. 20 (Garcia, Código Civil (3d ed. I9r4) 22) (H. Doc. No. 326 , p. 5 I0).

SwEDEN. Lag, om förvärfvande oct förlust af medborgaverátt, Oct. I, 1894, s. 5 (Svensk Författuings-Samling för 1894 (I895) No. 7I, p. 2) (H. Dac. No. 326, p. 514). Release from Swedish nationality will be granted by the king on condition that the individual acquires a foreign nationality within a specified time.

SwITzERLANd. Loi Fédéral sur la Naturalisation des Étrangers et la Renonciation à la Nationalité Suisse du 25 Juin 1903, Art. 7-9 (19 Recueil Officiel des Lois et Ordonnances, N. S. (I904) 654-655) (H. Doc. No. 326, p. 519). Release from Swiss nationality will be granted by the home canton, if person has no domicile in Switzerland, and if he has been naturalized in a foreign country.

TuRKEx. Loi sur la Nationalité du Ig Janvier 1869, Art. 5, 6 (2 Young, Corps de Droit Ottoman (I904) 227) (H. Doc. No. 326, p. 525). Foreign naturalization will not be recognized unless acquired with the government's permission.

URuguay. Constitucion, ro Setiembre de I829, Art. 12.3 (Criado, I Coleccion Legislativa (1879) I39) (H. Doc. No. 326, p. 534). Art. I2 of the proposed new constitution (Diario Oficial. Marzo aI de I9I7. Convencion Nacional Constitugente, 82) provides that citizenship shall be lost through naturalization in another country.

Venezuela. Ley de Naturalización, 24 de Mayo de 19r3, Art. 7, 8 (Gaceta Oficial. 27 de Mayo I9I3, No. Ir.930). Constitución, I8 de Junio de I9I4, Art. Io (Gaceta Oficial, IO de Jumio de I9I4). Change of nationality accomplished with the intent to escape the effects of a law, is regarded as fraudulent and void.

As to diplomatic correspondence between the United States Government and particular foreign countries respecting the question of expatriation see 3 Moore, 
Dig. of Int. Law, 586-7II, and citations given in note 46, supra, p. 496. As to the attitude of United States Government towards foreign governments with respect to expatriation and naturalization see Compilation of Certair Departmental Circulars relating to the Citizenship, Registration of American Citizers, etc. (Igr6) 62-75, also Borchard, op. cit. s. 237-240, 32I.

The text of foreign laws relating to nationality, expatriation, or naturalization may be found in the sources cited above or in the following works: For older laws see Opinions of the Heads of the Executive Departments and Other Papers relating to Expatriation, Naturalization and Change of Allegiance. United States Foreign Relations 1873, II, Ix97-I438. Nationality and Naturalization. Reports by Her Majesty's Representatives abroad upon the laws of foreign countries. Misc. No. 3 (1893) [Cd. 7027]; Martens, Nouveau Recueil Général de Traités. ze Série, Tome I9 (1895) 514 seq., giving the preceding reports.

For more recent laws see United States Foreign Relations; 3 Moore, Dig. of Int. Law, 276, references; H. Doc. No. 326, 59th Cong. 2d Sess. Appendix III; 2 Sieber, Das Staatsbürgerrecht im internationalen Verkehr (Igo7); Verhandlungen des Reichstags. XIII. Legislaturperiode. I. Session, IgI2. Anlagen No. 6, p. 72 seq.; Lehr, La Nationalité dans les Principaux États au Globe (I909); Cahn, Reichs- und Staatsangehörigkeitsgesetz (I9I4) 369 seq.; v. Keller und Trautmann, Kommentar zum Reichs- und Staatsangehörigkeitsgesetz (I914) 627 seq.; Zeballos, La Nationalité (Igr4); Rodriguez, American Constitutions (I906); Dodd, Modern Constitutions (I907); Oudin, État des Traités et Lois relatifs à la Nationalité et la Naturalization en vigueur dans les Principaux Pays au I5 Avril IgI7 (44 Journal du Droit Internationas (Clunet, I9I7) 8I7-84I), giving an almost complete list of references to the laws in force. 